\title{
Erratum to: Response Surface Methodology Optimization of Melanin Production by Streptomyces cyaneus and Synthesis of Copper Oxide Nanoparticles Using Gamma Radiation
}

\author{
Ahmed Ibrahim El-Batal ${ }^{1}$ - Gharieb Saied El-Sayyad ${ }^{1}$ • \\ Abbas El-Ghamery ${ }^{2} \cdot$ Mohamed Gobara $^{3}$
}

Published online: 28 August 2017

(C) Springer Science+Business Media, LLC 2017

\section{Erratum to: J Clust Sci (2017) 28:1083-1112 DOI 10.1007/s10876-016-1101-0}

The original version of this article unfortunately contained a mistake. The attribution in the 'Actinomycetes Strains' experimental section for the source of the actinomycetes used in the study was incorrect. The laboratory stated in the first paper was Medical Microbiology Laboratory in the Plant and Microbiology Department, Faculty of Science (Boys), Al-Azhar University, Cairo, Egypt however the correct affiliation is 'Bacteriology in Botany and Microbiology Department in faculty of science (Boys), Al-Azhar University’.

The online version of the original article can be found under doi:10.1007/s10876-016-1101-0.

Ahmed Ibrahim El-Batal

Ahmed.Elbatal@eaea.org.eg; aelbatal2000@gmail.com

Gharieb Saied El-Sayyad

Gharieb.Elsayyad@eaea.org.eg; adham_adham688@yahoo.com

Abbas El-Ghamery

a.el_ghamery@azhar.edu.eg; elghamery@hotmail.com

Mohamed Gobara

m_gobara@yahoo.com

1 Drug Radiation Research Department, National Center for Radiation Research and Technology (NCRRT), Atomic Energy Authority, P.O Box 29, Naser City, Cairo, Egypt

2 Botany and Microbiology Department, Faculty of Science (Boys), Al-Azhar University, Cairo, Egypt

3 Chemical Engineering Department, Military Technical Collage, Cairo, Egypt 